\title{
Correlation Of Socio-Cultural Education Foundation With Increased Social Child Development
}

\author{
I Ketut Sudarsana ${ }^{1}$, Erwin Putera Permana ${ }^{2}$, Dian Rianita ${ }^{3}$, Nurintan Asyiah Siregar ${ }^{4}$, Ainna \\ Amalia $^{5}$, Ni Ketut Kantriani ${ }^{6}$, Ni Ketut Sri Ratmini ${ }^{7}$, I Nyoman Nadra ${ }^{8}$, Yulfia Nora ${ }^{9}$ \\ \{iketutsudarsana@uhnsugriwa.ac.id $\left.{ }^{I}\right\}$ \\ Universitas Hindu Negeri I Gusti Bagus Sugriwa Denpasar, Bali, Indonesia ${ }^{1,6,7,8}$, Universitas Nusantara \\ PGRI Kediri, Indonesia ${ }^{2}$, Faculty of Administration - Universitas Lancang Kuning, Pekanbaru, \\ Indonesia ${ }^{3}$, Department of Management, STIE Labuhanbatu, Sumatera Utara, Indonesia ${ }^{4}$, Islamic \\ Institut of Miftahul Ula Kertosono Nganjuk, East Java, Indonesia ${ }^{5}$, Elementary School Teacher \\ Education Program, Faculty of Teacher Training and Education, Universitas Bung Hatta, Padang, \\ Indonesia ${ }^{9}$
}

\begin{abstract}
Philosophically social culture is a part of human life that is closest to daily life. Every human activity is almost never lost of the socio-cultural elements. Indeed, the socio-cultural aspect is naturally owned human beings, where humans are social being that need a good interaction in their life, either individual, society and individual society. Intend to socio-cultural foundation in education it is so needed because it will make a life foundation become strong and it would be needed for human being in the future to know their identity of himself especially for learners in developing the social psyche and culture through educational foundation. Education and culture must be aligned and mutual advance each other. Thereby the more people receive education will make the human being become cultured and the higher culture will make the higher education.
\end{abstract}

Keywords: Socio-Cultural Education; Social Child Development

\section{Introduction}

Theoretically the purpose of education is one of the important educational component, because it will give direction to the process of educational activities. All educational activities or learning activities directed to achieve learning objectives [1]. Intend to the purpose of national education from different cultural indonesian roots there is an law of the national education system, namely law No. 20 in 2003 declared national education aimed at the potential development of learners to become human faith and pious to God Almighty in precious, healthy, knowledgeable, competent, creative, independent and become citizens of a democratic and accountable [2].

In accordance with some sense above, it can be concluded that education is very necessary to print the next generation a nation that will be able to increase their knowledge to the younger generation so that it will be a success of concept, it's humanizing of human Education serves to develop the ability in character and the civilization of the peoples dignity in the intellectual life of the nation.

Empirically the culture foundation in education is the culture cultivation will create a better life. It can be used as a shield which could be able to stem the era of globalization. Given the phenomena that occur in the community nowadays many changes or shifts that 
occur especially in the social and cultural sphere until so many negative influences that occur in life especially the younger generation.

Pragmatically will be useful as a practical reference in the governance of education system which is based on socio-cultural education in improving the social development of children [3]. it can be used as a reference point Indeed for considering the more rapid changes in the social development of the child as a result of the globalization era. The Phenomenon that occur in the social development of children in an era of globalization are having a dilemma that towards negative. Thus it is very necessary to look for a solution can change towards good. The foundation of social culture in education will be able to encourage their identity to be able to have a good social development indeed.

\section{Method}

The type of research used in this scientific work is qualitative research. The data collection methods used in this research are: interview and literature study. The technique of determining informants used is purposive sampling technique, namely the determination of informants based on the consideration of researchers based on knowledge, experience and relevance to this research. Analysis of the data used is descriptive analysis by conducting a study of an objective phenomenon in accordance with the literature and field data.

\section{Result and Discussion}

\subsection{Correlation Of Socio-Cultural Education Foundation With Increased Social Child Development}

Correlation of socio-cultural foundation of education is indispensable for increasing social development of chid. It is required for using as a shield of life in this globalization era which has been leading towards negative. As for the changes that occur include changing ways of thinking, communicating and the behaviour of the child. Thus it makes a dilemma that occurred in the development of child. Behaviour changing in children is affected by several factors which caused By social interaction process that occur are:
a) Imitation
b) Suggestion
c) Identification
d) Simpathy

These factors explain that the existence of the inconsistent mindset process. This required an actual coaching in structured so that the child's development can be directed towards the positive. It takes a balance of social and cultural interaction providing in education. Plato said that the purpose of education is the awareness towards self knowing and self realization then inquiry and reasoning and logic [2]. Thus it can be concluded that the purpose of education is a process which leads to get knowledge but required an understanding and also the classification of the science we have, then doing a study get truth so that it can be known causal relation, namely reason and mindset. 
Education is fundamental, base or foundation strengthening and empowering the world education in order to create a quality education. The quality of education in the Depdikas complete as a "quality and relevance". One of the principal issues in education is the quality of education. Indeed there are five strategic issues with regard to the quality of education, namely: quality curriculum, graduates, teachers, supporting infrastructure and textbooks [4].

In accordance with the explanations needed a curriculum that contains the value of the cultivation of social interaction concept and also culture to guide and enhance child development, so it would be strengthen their character better. Graduates who referred to is how make graduates who have a balance between soft skills (emotional intelligence) and hard skills (mastery of science). Teachers should also be able to coaching and providing guidance to become a supervisor who can develop the social development of children. Supporting infrastructure and textbooks will also affect achievement of education purpose.

The providing concept of socio-cultural education will be able to become a filter process to provide guidance and coaching for children to be able to think in "meaningfulness" it's required a process of maturity in accepting a changes [5]. According to Bloom that behaviour changes happened in three domains, namely changes in the cognitive domain be incremented and the more powerful concept of knowledge, affective change in the form of growing and increasing conciousness and awareness of the functions and knowledge meaningfulness, and psychomotor changes that show the more growing skills and in the future could lead to him survive [2]. Thus it can be used as a reference in the providing concept of education for a culture of soial Foundationto improve children social development.

\subsection{The correlation effect of Socio-Cultural Education Foundation With Increased Social Child Development}

The correlation impact of socio cultural education foundation with the increase in social development of the child, namely:

a. The child's character embodies the cultural

The foundation of socio-cultural education applied and used as a base in the curriculum, because education and culture also cannot be separated because it is identity from the nation. Where a growing number of children receive an education will make the child be cultured and the higher culture will make the higher education. Thus if it can be realized in the education, it will be formed or showed an child characters cultured and also this will have an impact to the increase in child development.

b. Cultural Transmission

The cultural transmission is a process of providing and preservation concept of culture in order to make the child be cultured and also needed a social interaction for increasing social development of children. the multiplicity of phenomena that occur in child development towards the negative, already the three education education such as informal, formal and nonformal should be synergized to provide understanding and also the right direction as it always gives the social culture based education, so that it will become an daily the behaviour of child.

c. Social Controling

Social Controling functions as a filter for the child against the currents of change and think in "meaningfulness" it will form the maturity of thinking. Couching culture is needed and always trying thinking are mature, so that it can become a habit that was potitif in taking a decision. 
d. Harmonization between formal, informal and nonformal

A balance needed between education process in the family, at school and education environment. Because those the concept related with how process of changing interplay of character in children. If it is less then one will be able to influence how social interaction and culture that is owned by the child. Thus the necessary awareness for all to support and create a harmonization in life.

The Hinduism teaching concept, there are two simple dimension that can be used as a source in social development increase those are Pradnyan and purusotama. Pradnyan is the intelligence [6]. Thus children should be using awarnesses to be able to think maturely until will formed character children and also reflects the pride people [7]. While Purusotama is good morals. It needs wherever we intelligence and high morality, then it will make harmonization in social developments children increasingly.

\section{Conclusion}

a) Socio-cultural educational of providing concept will be able to become a filter process to provide guidance and coaching for children to be able to think in "meaningfulness" so that required a process of maturity in accepting a changes. The more children receive an education will make the child be cultured and the higher culture will make the higher education.

b) The Hinduism teaching concept, there are two simple dimension that can be used as a source in social development increase those are Pradnyan and purusotama. Pradnyan is the intelligence. Thus children should be using awarnesses to be able to think maturely until will formed character children and also reflects the pride people of Bali. While Purusotama is good morals. It needs wherever we intelligence and high morality, then it will make harmonization in social developments children increasingly.

\section{References}

[1] R. Yudhawati, Teori-Teori Dasar Psikologi Pendidikan. Jakarta: PT. Prestasi Pustakaraya, 2011.

[2] M. Sukardjo, Landasan Pendidikan Konsep dan Aplikasinya. Jakarta: Rajawali Pers, 2013.

[3] The Lancet, "Gender equity is the key to maternal and child health," The Lancet, 2010.

[4] R. Nugroho, Pendidikan Indonesia: Harapan, Visi, dan Strategi. Yogyakarta: Pustaka Pelajar, 2008.

[5] M. Pidarta, Landasan Kependidikan Stimulus Ilmu Pendidikan Bercorak Indonesia. Jakarta: Rineka Cipta, 2013.

[6] I. K. Sudarsana, "Interpretation Meaning of Ngaben for Krama Dadia Arya Kubontubuh Tirtha Sari Ulakan Village Karangasem District (Hindu Religious Education Perspective)," Vidyottama Sanatana Int. J. Hindu Sci. Relig. Stud., vol. 1, no. 1, pp. 1-13, Jun. 2017.

[7] F. Fincham and J. Jaspars, "Attribution of responsibility to the self and other in children and adults,” J. Pers. Soc. Psychol., 1979. 